\title{
FACIAL CHARACTERISTICS OF KIMBERLITE ROCKS FROM THE NORTHERN AND SOUTHERN PARTS OF THE YAKUTIAN KIMBERLITE PROVINCE (IN THE LIGHT OF THE DUKEN AND DALDYN KIMBERLITE FIELDS)
}

\author{
Emma Shamshina, Zinaida Altukhova and Svetlana Babushkina \\ Diamond and Precious Metal Geology Institute Siberien Branch, Russian Academy of Sciences, Russia
}

The Yakutian kimberlite province (YKP) includes several hundred kimberlite bodies, but only a few of them contain diamonds in economic quantities. They are mainly located in the southern part of the province. There are two main concepts explaining different diamond tenor of the southern and northern parts of the YKP. These are: 1) specific geodynamic environments in which the kimberlite bodies were formed and 2) vertical zoning of a composite magmatic column. The latter concept assumes that the rocks of the kimberlite formation belong to two facies: intrusive and subexplosive. The former make up dikes and stocks of kimberlite and alnoite, while the latter comprise prepipe and intrapipe vein bodies, pipes proper, and sills occurring near the pipes. The upper levels of the magmatic column correspond to the most productive diamondiferous diatremes, whereas the lower ones are less rich in diamonds. At the same time, there is a certain zoning pattern observed in the vertical section of the studied diamondiferous pipes in the southern part of the province. Deep horizons of the pipe structures are made of subintrusive rocks distinctly differing in the composition of olivines, garnets, and chrome-spinellide. There are also pipes abruptly changing their form with depth (Aikhal) and those consisting of several smaller bodies. Since the level of denudation erosion of the kimberlite bodies of the YKP increases from 300-400 $\mathrm{m}$ to $2 \mathrm{~km}$, the similarity of mineralogical and petrographical features between the kimberlite rocks from the northern part and subintrusive rocks from deep levels of the pipes in the southern part can be explained in terms of vertical mineralogical and petrographical zoning of the kimberlite pipes. Clusters (chains) of closely spaced pipes observed in the areas of high denudation erosion could represent, at higher hypsometric levels, conjugate pipes. In view of 30 findings of diamond in some kimberlite bodies of the Duken field and new $\mathrm{Rb}-\mathrm{Sr}$ dates obtained, the task was set to identify the rocks composing numerous bodies within the field with the aim to establish typomorphic features of their facial affinity.

The Duken kimberlite field is located on the eastern side of the Anabar uplift, in the Big Kuonamka and
Small Kuonamka interfluve. The field is about 1800 $\mathrm{km}^{2}$ in area. By now, over a hundred kimberlite bodies have been discovered there. In plan they are oval and, rarely, isometric in shape, ranging in size from a few tens of meters to 70-100 m (Fig. 1). Dikes as thick as 5$10 \mathrm{~m}$ are traceable over a distance of $270 \mathrm{~m}$. The kimberlite bodies intrude into terrigenous-carbonate rocks of Middle-Riphean-Early Cambrian age and are overlain by thin Quaternary deposits. They are coeval with thin near-contact breccias with a high proportion of the host rock fragments. Many of the kimberlite bodies with similar magnetic properties have a complex structure due to the presence of rocks of varying composition.

Age determinations of the kimberlite rocks of the Duken field were performed at the laboratory of mass spectrometric analysis of the Diamond and Precious Metal Geology Institute, Siberian Branch, Russian Academy of Sciences under the supervision of A.I. Zaitsev. Geochronological dating was made by $\mathrm{Rb}-\mathrm{Sr}$ isotope method on microlitic phlogopite from kimberlites and the groundmass of kimberlite breccias. The results of new age determinations of kimberlite rocks from the Duken field showed the existence on its territory of two stages of kimberlite magmatism: Late Devonian-Early Carboniferous (320-346Ma) and Late Jurassic (140-205Ma). Besides, absolute age determinations revealed the presence in the Duken field, as in other fields of the YKP, of polychronous (different-aged) bodies.

Most of the anomalies within the study area are filled with fine-porphyritic kimberlite with various mineral associations of the groundmass. Phenocrysts with a size of 0.5 to $2 \mathrm{~mm}$ consist of olivine, serpentinized to a varying degree, phlogopite, and rarely monticellite or ilmenite. The ratio of the phenocrysts to the groundmass ranges from 30 to $60 \%$. Typical are fine (1$2 \mathrm{~cm}$ ) inclusions of phlogopite-bearing olivinites (serpentinized) showing different degrees of granulation and dissolution. The groundmass of the kimberlites includes several mineral associations 


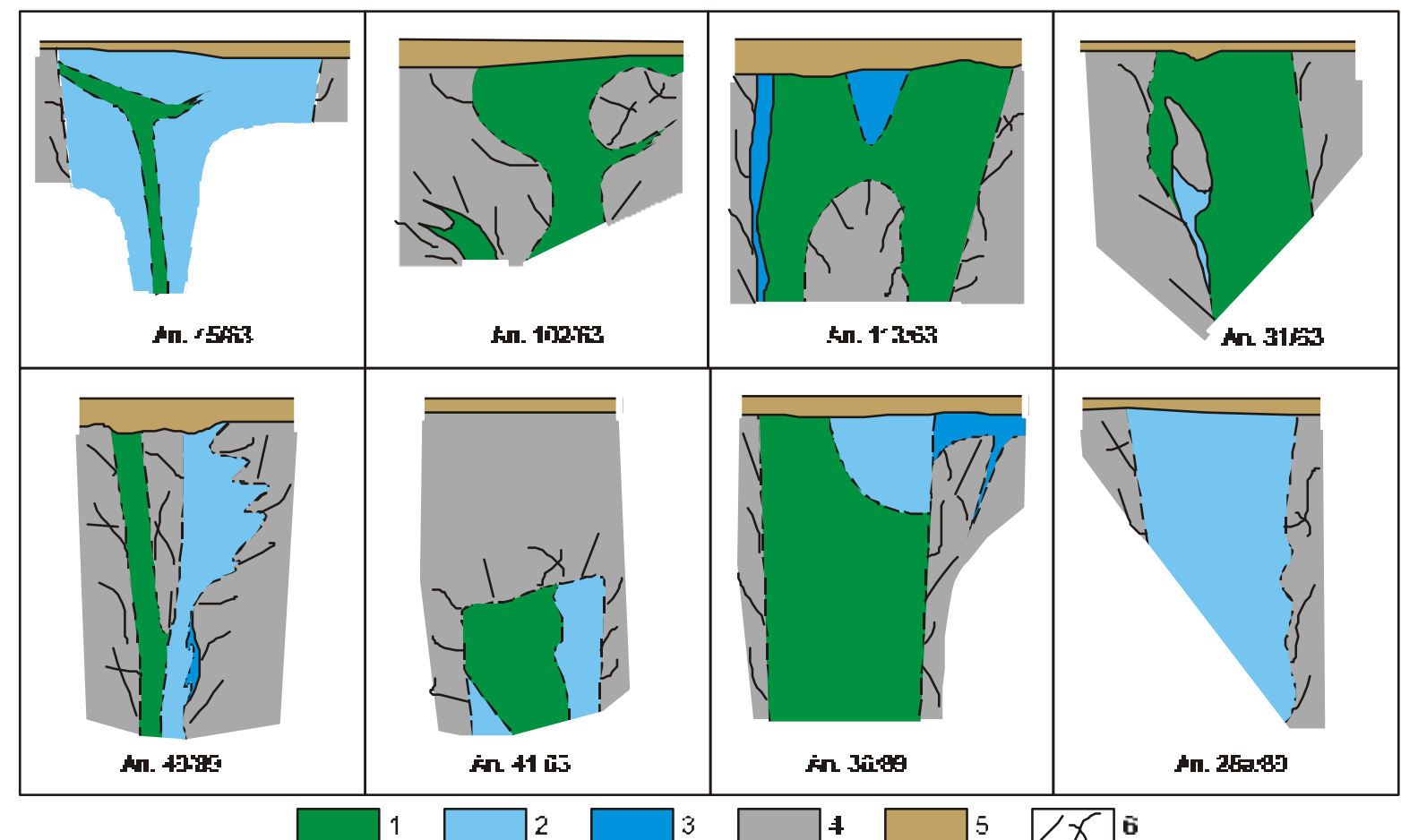

Figure 1 Spatial relationships of kimberlite breccias and kimberlites with the host rocks and within the kimberlite bodies of the Duken field (schematic sections are constructed after Prokopiev S.A. and Egorova P.E., AmGRE). 1 kimberlite; 2 - kimberlite breccia; 3 - near-contact breccia; 4 host rocks $\mathrm{R}_{2}-\mathrm{C}_{1} ; 5$ - overlying rocks $\mathrm{Q}_{\mathrm{III}}-\mathrm{Q}_{\mathrm{IV}} ; 6$ - direction of jointing.

changing one another in the following sequence: olivine-phlogopite, monticellite, and carbonate-apatite.

The olivine-phlogopite associations is distinguished by a high content of idiomorphic perovskite grains and a panautomorphic-granular texture. With high phlogopite proportions the porphyritic texture is illdefined due to the absence of a fine-grained or hypocrystalline groundmass. The texture is quite distinct when olivine and phlogopite phenocrysts are set in a fine-grained groundmass of phlogopite-serpentine composition. Phlogopite is often found to be hydrated, colorless, and replaced by isotropic serpentine.

In monticellite varieties prevailing are phenocrysts of variously serpentinized olivine, often with monticellite rims. Fine-grained monticellite is locally found inside of serpentinized olivine grains. Monticellite of the groundmass is characterized by irregular distribution and wide size variations $(0.01$ to $0.6 \mathrm{~mm})$. The groundmass locally consists completely of isometric monticellite grains. The amount of isotropic serpentinite filling interstices between the grains of monticellite and phlogopite ranges from 10 to 25 vol.

$\%$, defining either a hypocrystalline or a fine-grained texture. The presence of monticellite as rims around the

olivine grains and as inclusions in hydrated and serpentinized phlogopite is indicative of its later reaction origin.

In the carbonate-apatite varieties calcite replaces serpentine pseudomorphs after olivine, defining either a fine-grained or a microlitic texture of the groundmass. The carbonate mass contains phlogopite plates, prismatic olivine grains, as well as serpentine and chlorite. Perovskite and ore minerals occur as relics, indicating metasomatic transformation of the primary olivine-phlogopite varieties of the kimberlites with a high proportion of xenoliths into largely carbonate rocks.

The kimberlite breccias contain 7-10 \% xenoliths ranging from 1 to $4 \mathrm{~cm}$ in size. They consist of serpentinized metamorphic rocks, fine-grained limestones, and clay shales. The cementing kimberlite is characterized either by the presence or absence of autoliths.

The massive kimberlite breccias contain two groups of olivine phenocrysts differing in size and shape. The first group includes round or oval grains of serpentinized olivine more than $2 \mathrm{~mm}$ in size. Their amount does not exceed 5\%. Prevailing are idiomorphic and hypidiomorphic olivine phenocrysts of the second group with a size of 1-2 $\mathrm{mm}$.

The autolithic kimberlite breccias contain up to 10$15 \%$ sedimentary xenoliths. Also present are small $(1.2 \times 1.5$ and $2 \times 3 \mathrm{~cm})$ cored and free-core autoliths. They do not exceed $5 \%$ in quantity. The cores are made of olivine phenocrysts and small $(1-1.5 \mathrm{~cm})$ inclusions 


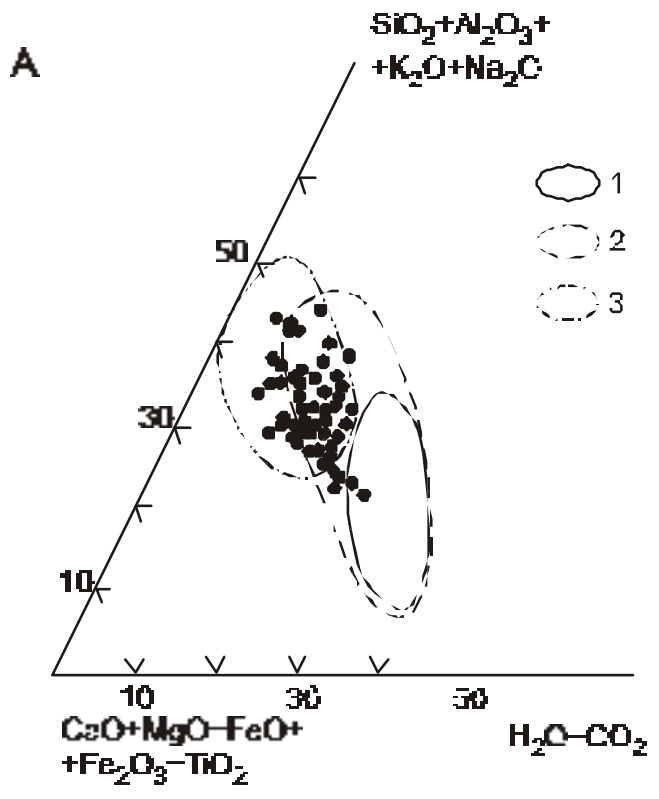

B

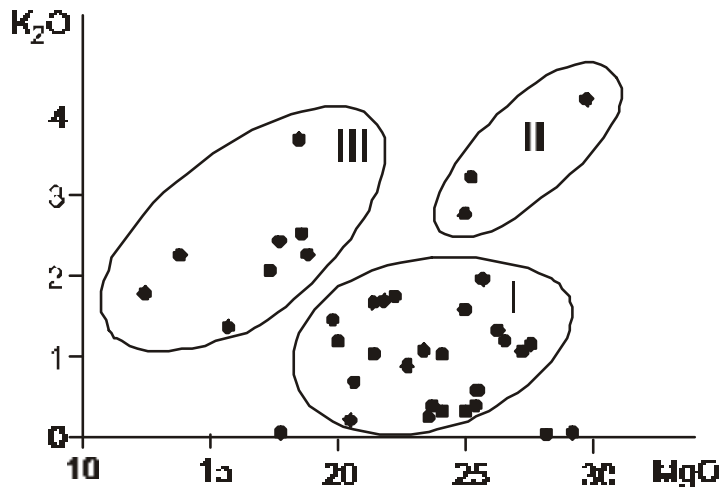

Figure 2: Chemical characteristics of kimberlites of the Duken field. A- Holmes' diagram: 1-kimberlite and alnoite field; 2-kimberlite breccia field; 3-carbonatite field; B$\mathrm{K}_{2} \mathrm{O} / \mathrm{MgO}$ ratio (I-olivine-serpentine; II-olivine-phlogopite; III-carbonate-phlogopite varieties).

of phlogopite-bearing olivinites or serpentinites. The width of aphyric rims is $23 \mathrm{~mm}$. The autoliths are relics of unaltered rock of olivine-melilite or olivinephlogopite composition with a high proportion of perovskite and ore minerals. They are set in a carbonatized cementing mass. In melilite-phlogopite autoliths, prismatic-oblong grains of melilite occur between the phlogopite plates.

The cementing mass of the autolithic kimberlite breccias consists of intensely carbonatized and serpentinized rocks with the relics of perovskite and ore minerals.
Petrochemical characteristics of the rocks of the Duken field are defined by high $\mathrm{MgO}$ and low $\mathrm{SiO}_{2}$ contents as a result of large amounts of olivine and its low degree of serpentinization. High proportions of $\mathrm{TiO}_{2}$ and total $\mathrm{Fe}$ (ca. 13\%), with $\mathrm{Fe}_{2} \mathrm{O}_{3}$ more than twice as much as $\mathrm{FeO}$, are due to constantly present unaltered perovskite and titanomagnetite. The kimberlites show wide variations in $\mathrm{K}_{2} \mathrm{O}$ and volatiles. Relatively high amount of $\mathrm{Na}_{2} \mathrm{O}$ (up to $0.8 \%$ ) is characteristic of sporadic melilite-bearing rock varieties. The kimberlite rocks of the Duken field show directly proportional $\mathrm{MgO}-\mathrm{SiO}_{2}, \mathrm{CaO}-\mathrm{CO}_{2}, \mathrm{MgO}-\mathrm{H}_{2} \mathrm{O}$, $\mathrm{H}_{2} \mathrm{O}-\mathrm{SiO}_{2}$, and $\mathrm{CaO}-\mathrm{P}_{2} \mathrm{O}_{5}$ and inversely proportional $\mathrm{CaO}-\mathrm{MgO}, \mathrm{H}_{2} \mathrm{O}-\mathrm{CO}_{2}$, and $\mathrm{H}_{2} \mathrm{O}-\mathrm{CaO}$ relationships, characteristic of all kimberlites of the YKP. Primary composition of the rock is reflected by $\mathrm{SiO}_{2}, \mathrm{TiO}_{2}, \mathrm{FeO}$ and $\mathrm{H}_{2} \mathrm{O}$ associations. Negative correlations between low $\mathrm{CaO}$ or $\mathrm{CO}_{2}$ and the above-mentioned oxides are indicative of carbonate metasomatosis that resulted in a gradual decrease in the amount of primary minerals due to their replacement by calcite. Phlogopite occurs in paragenetic associations with both olivine and carbonate.

On Holmes' diagram (Fig. 2A) all compositional points of the kimberlite rocks plot into the field of kimberlites and monticellite alnoites. Deviation of some points toward the field of carbonatites reflects a similarity of chemical compositions between the carbonatized kimberlites and carbonatites. The difference between them is in the absence of a specific carbonatite mineralization in the former. Chemical specialties of monticellite kimberlites include the prevalence of $\mathrm{CaO}$ over $\mathrm{CO}_{2}$ and low $\mathrm{H}_{2} \mathrm{O}$ and $\mathrm{CO}_{2}$ amounts. As seen from the $\mathrm{K}_{2} \mathrm{O}-\mathrm{MgO}$ correlation diagram (Fig. 2B), the points of kimberlites with contrasting $\mathrm{K}_{2} \mathrm{O}$ amounts fall into the field of high $\mathrm{MgO}$ contents, reflecting both the olivine-phlogopite and olivine-serpentine-perovskite compositions. Compositional points of carbonatephlogopite rocks form clusters in the field of low $\mathrm{MgO}$ contents.

Many of the Daldyn field kimberlite pipes have a complex structure. They consist of two varieties of kimberlite breccias: massive and autolithic. Characteristic features of the massive kimberlite breccias are a low proportion of sedimentary xenoliths, mainly in the near-contact zones, and a large amount of small ultrabasite inclusions (10-15\%). The cement of such breccias has a porphyritic text ure and a finegrained groundmass. The phenocrysts consist of olivine, serpentinized to a varying degree, as well as ilmenite, pyrope, and phlogopite. The groundmass includes the following mineral assemblages: monticellite-serpentine, phlogopite-serpentine, phlogopite-carbonate, and serpentine-apatite. 
Monticellite of the monticellite-serpentine breccias has, as in the kimberlites, reaction and late magmatic origin. Fine idiomorphic monticellite grains form margins around the olivine grains, occur as inclusions in large altered phlogopite plates, and are irregularly distributed in the groundmass.

The phlogopite-serpentine associations of the massive breccias is characterized by a high phlogopite content $(20-40 \%)$. It mainly occurs as fine $(0.01 \times 0.1$ $\mathrm{mm}$ ) randomly oriented plates, in association with perovskite and titanomagnetite, included in the serpentine mesostasis.

The phlogopite-carbonate associations contains both microlitic forms and large plates, defining either a microlitic or a prismatic texture. Relics of primary phlogopite occur as rounded, rarely pseudohexagonal, and sometimes fragmental grains. Their distinct pleochroism and characteristic cleavage indicate they had a common source.

The serpentine-apatite groundmass consists of shortprismatic apatite grains in association with perovskite and titanomagnetite that are regularly distributed in the isotropic basis of serpentine composition.

Autolithic kimberlite breccias. They completely make up most of the simple pipes and constitute much of the volume of the complexely structured bodies. Unlike in the Duken field, breccias of the Daldyn field have a distinct autolithic structure. The autoliths exhibit a wide variety of forms and structures, ranging in size from microscopic to as large as $10 \mathrm{~cm}$ and more across. They are conventionally classified into cored and core-free varieties. It is the cored autoliths that define a peculiar outlook of the breccias making up bodies of the Daldyn field. The near-contact breccias at deep levels of the pipes have here, as in the Duken field, a microautolithic structure. At a depth of 500-700 m, core-free autoliths are prevalent, which are analogous to massive kimberlite breccias making up blocks in the pipes of complex structure. Rarely found are autoliths of phlogopite (up to $30 \%$ ) or apatite composition with a panautomorphic-granular texture. They appear to be inclusions of the rocks from the root zones of the pipes. Petrochemical characteristics of the massive kimberlite breccias with high-temperature mineral associations within the Daldyn kimberlite field are, in general, similar to those in the Duken field. The difference is in higher $\mathrm{H}_{2} \mathrm{O}$ and $\mathrm{MgO}$ contents of the massive breccias in the Daldyn field, which are due to their higher degree of serpentinization. Aphyric rims of the cored autoliths are found to be high in $\mathrm{K}_{2} \mathrm{O}(2-3 \%)$ and $\mathrm{P}_{2} \mathrm{O}_{5}$. The data indicate that products of phlogopite and apatite dissolution accumulated in a homogeneous liquid phase of the kimberlite magma. They were preserved in the rims that resulted from rapid magma solidification due to instantaneous separation of volatiles at the upper levels of the magmatic column.

Minerals-"sputniks" of diamond in the kimberlite rock of the Duken field are olivine, clinopyroxene, ilmenite, garnet, and chrome-spinel. Olivine exhibits wide variations in fm ratio (from 7 to $18 \%$ ), with most of the grains showing $9-12 \%$. Five olivine grains with the fm ratio of 6-18\% were found in the Middle Paleozoic rocks and three were encountered in the rocks of Late Mesozoic age.

Most of the studied pyroxenes are diopsides and diopside-augites. They contain $0.7-3.6 \% \quad \mathrm{Cr}_{2} \mathrm{O}_{3}, 0.1-$ $3.1 \% \quad \mathrm{Na}_{2} \mathrm{O}$, and $0.1-4.1 \% \quad \mathrm{Al}_{2} \mathrm{O}_{3}$. On Eu-Wo-Fs diagram (Fig. 3A), they plot into the fields of pyroxenes from diamondiferous lherzolites and pyroxene inclusions in diamonds and phlogopites. Their crystallization temperature is estimated at $800-1100^{\circ} \mathrm{C}$. One of the grains has augite composition $\left(\mathrm{T}=1200^{\circ} \mathrm{C}\right)$ and is analogous to that from clinopyroxene-ilmenite intergrowths of kimberlites. Most of ilmenites on IlmHm-Gk diagram (Fig. 3B) fall into the fields of ilmenite megacrysts from kimberlites and their analogues from ilmenite hyperbasites. Some of the grains ( $\mathrm{Hm}<10 \%)$ are analogous to ilmenites of diamond paragenesis. The amount of hematite component is less than $20 \mathrm{wt} \%$ for practically all the studied samples, which is the evidence for their xenogenic origin. A group of grains with the amount of ilmenite minal of more than 80 wt.\% is distinguished, which are compositionally similar to ilmenite megacrysts from alkali basaltoids and to ilmenite inclusions in an anomalously ferruginous garnet megacryst from the Udachnaya pipe. All the garnets studied are pyropes of different mantle parageneses (Fig. 3C). Prevalent are garnets from lherzolites with wide $\mathrm{Cr}_{2} \mathrm{O}_{3}$ and $\mathrm{CaO}$ variations. On the average, they contain 68 wt.\% Prp, $9.7 \%$ Alm, $7.7 \%$ Knr, $6.8 \%$ Adr, and 5.7.\% Uvr. TiAdr and Sps are present in the amount of less than $1 \%$. Less common are pyropes from magnesian-ferruginous pyroxenites. As compared to the previous pyropes, the amount of the pyrope minal in them is reduced to $59 \%$, while the rest minals increase (Alm- 11.1\%, Knr -10.9 \%, Uvr-9.9\%, Adr-7.5\%). Sps is also found in the quantity of $1 \%$. There are also some garnet grains characteristic of websterites. They show minimal $\mathrm{Cr}_{2} \mathrm{O}_{3}(<1 \%)$ and $\mathrm{CaO}$ $(<5 \%)$ contents. With regard to their crystallochemical composition they correspond to Alm 21.5-Prp 67.2, with a large amount of andradite component (9.2\%). And finally, there are two grains of harzburgite-dunite paragenesis, Knr 32.9-Prp 48.8, with more than 9\% $\mathrm{Cr}_{2} \mathrm{O}_{3}$, the maximum value registered for the studied 

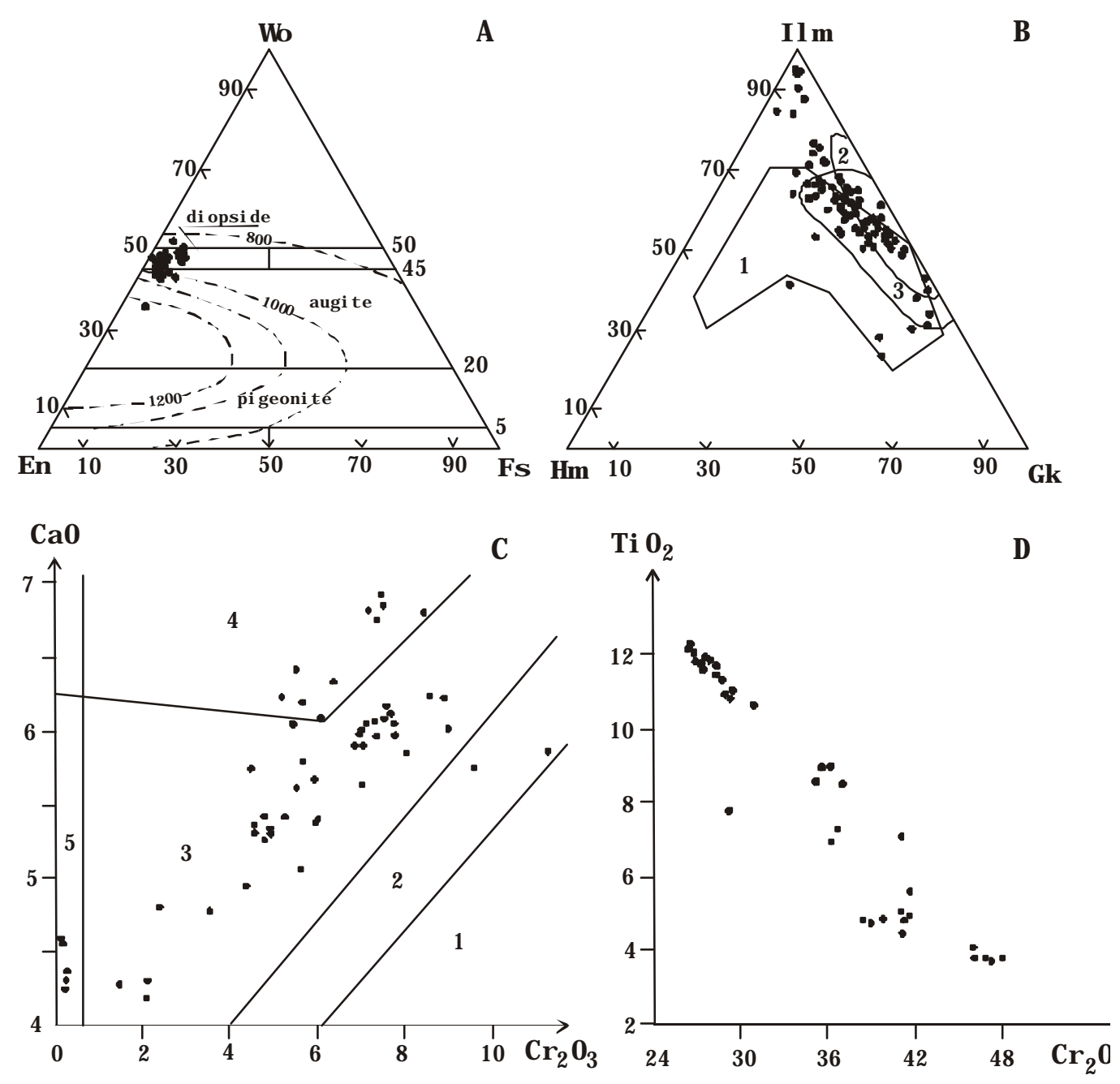

Figure 3. Chemical characteristics of minerals from the kimberlite rocks of the Duken field: A-pyroxene, B-ilmenite (1-megacrysts, 2-diamond paragenesis, 3-inclusions in phlogopite); Ggarnet (1-diamond, 2harzburgite-dunite, 3 lherzolite, 4-pyroxenite, 5-websterite parageneses); D-spinel.

garnets. The grains are also high in the almandine $(11 \%)$ and uvarovite $(9.5 \%)$ minals.

The chrome-spinels studied are compositionally similar to those from garnet lherzolites. They contain $412 \%$ $\mathrm{TiO}_{2}, 26-48 \% \mathrm{Cr}_{2} \mathrm{O}_{3}$, and 7-16\% $\mathrm{Al}_{2} \mathrm{O}_{3}$ (Fig. 3D).

1. Widespread occurrence on the territory of the Duken field of small kimberlite bodies of complex structure, indistinct autolithic structure of the kimberlite breccias that resulted mainly from near-contact brecciation, and similar chemical compositions of kimberlites and kimberlite breccias are all features indicating that the kimberlite bodies studied are root zones of kimberlite diatremes.
2. Middle Paleozoic age of some of the bodies and a high level of their denudation erosion suggest a wide distribution of the subexplosive facies of kimberlite bodies in the study area.

3. The relationship between the intrusive and explosive processes is supported by the findings in the kimberlites of the Duken field of indicator minerals typical of diamondiferous kimberlite breccias.

4. The evidence for the relationship between the studied rocks of the subintrusive and subexplosive facies is the presence in the latter of autoliths of phlogopiteperovskite or carbonate-phlogopite-apatite composition and the occurrence of monticellite and apatite in the massive kimberlite breccias at deep levels of the pipes in the southern part of the Yakutian kimberlite province. This process is common for the entire province.

Contact: E-mail: e.a.shamshina@diamond.ysn.ru. 